\title{
Development of a double-recombinant antibody sandwich ELISA for quantitative detection of epsilon toxoid concentration in inactivated Clostridium perfringens vaccines
}

\author{
Maryam Alibeiki', Mehdi Golchin ${ }^{2}$ and Mohammad Tabatabaei ${ }^{*}$
}

\begin{abstract}
Background: Epsilon toxin (ETX) causes a commonly fatal enterotoxemia in domestic animals. Also, ETX causes serious economic losses to animal husbandry. In this study, we selected several clones against ETX using repertoires displayed on filamentous phage. Anti-ETX specific clones were enriched by binding to immobilized antigen, followed by elution and re-propagation of phage. After multiple rounds of binding selection, ELISA analysis showed that most isolated clones had high affinity and specificity for ETX.

Results: Two recombinant monoclonal antibodies against ETX were isolated by phage display technology. $\mathrm{B}_{1}$ phage $\mathrm{VH}$ antibody isolated from DAb library and $\mathrm{G}_{2}$ soluble scFv antibody isolated from Tomlinson I + J libraries have been applied as the capture and detection antibodies for developing an ETX sandwich ELISA test, respectively.

Conclusions: Designed ETX sandwich ELISA could be a valuable tool for quantitative detection of ETX in inactivated commercial vaccines against enterotoxemia.
\end{abstract}

Keywords: Epsilon toxin, Clostridium perfringens, Recombinant antibody, Phage display, Sandwich ELISA

\section{Background}

Epsilon toxin (ETX) is a $33 \mathrm{kDa}$ protein and one of the pore-forming toxins synthesized by Clostridium perfringens type B and D strains [1]. ETX has high potency and the Centers for Disease Control and Prevention (CDC) categorized epsilon toxin as the second highest priority agents (Category B) [2]. This toxin plays a significant role in causing enterotoxemia in domestic ruminants, especially sheep, and can cause sudden death and severe economic losses [3]. Enterotoxemia begins when C. perfringens type B or D

\footnotetext{
* Correspondence: mtabatabaei2003@yahoo.co.uk

'Department of Pathobiology, Faculty of Veterinary Medicine, Shiraz University, Shiraz, Iran

Full list of author information is available at the end of the article
}

strains secrete ETX prototoxin into the intestinal lumen [4]. At first, the toxin is inactive, but it is activated after cleaving the $13 \mathrm{~N}$-terminal and $22 \mathrm{C}$-terminal residues by proteases [5]. After activation, ETX forms the pores across the cell membrane of ruminant cells and alters the permeability of cell monolayers, such as epithelium and endothelium, and leads to necrotic lesions and perivascular edema in different tissues, especially in kidney and brain cells $[6,7]$. An effective manner to control ETX-induced enterotoxemia in domestic ruminants is vaccination. Commercially available vaccines are based on inactivated toxins isolated from formaldehyde-treated bacterial culture filtrate. Unfortunately, these vaccines usually have many production defects and have variable immunogenicity. One 
of these defects is the non-uniform concentration of antigens in each batch that leads to potency variation from batch to batch [8-11]. Therefore, developing new methods for the detection and quantitative measurement of antigens in each batch of the vaccines is required. One of the most appropriate methods for quantitative detection of a specific protein in a complex mixture is sandwich Enzyme-Linked Immunosorbent Assay (ELISA) that is used as a common tool for clinical and research programs. As a rapid analysis and inexpensive assay, ELISA has many benefits like sensitivity, specificity, simplicity, and stability [12-14].

The aim of this study was to isolate specific recombinant antibody fragments from Human Domain Antibody (DAb) and Tomlinson I $+\mathrm{J}$ libraries as capture and detector antibodies for developing a sandwich ELISA for quantitative detection of ETX in inactivated commercial enterotoxemia vaccines.

\section{Results}

\section{Biopanning of phage display libraries}

At first, the molecular size and purity of the epsilon toxoid were confirmed by SDS-PAGE. Then to isolate specific phage antibodies against ETX, two selections in three rounds were performed using the Tomlinson $\mathrm{I}+\mathrm{J}$ and DAb libraries. In each round of selection, the phages with a binding affinity for ETX were isolated. After amplification, the phages were used for the next round of selection.

\section{Screening of clones by polyclonal and monoclonal phage ELISA}

The populations of phage recovered after each round of selection from each library were screened against ETX by polyclonal phage ELISA. The results of polyclonal
ELISA tests showed that the reactivity towards the epsilon toxoid increased from the first round to third round, respectively. These results indicated that phage antibodies reactive with epsilon toxoid were successfully isolated and enriched from both libraries (Fig. 1a ).

Also, phages were prepared individually from clones of second and third rounds of selection from each library (Tomlinson $\mathrm{I}+\mathrm{J}$ and $\mathrm{DAb}$ ) for analysis by monoclonal phage ELISA. As Fig. 1b shows, most of the isolated clones, especially from Tomlinson I $+\mathrm{J}$ libraries had a high affinity toward antigen.

In the next steps, the best-isolated clone from monoclonal scFv ELISA of Tomlinson I + J libraries (Clone No. $G_{2}$ ) was used for expression soluble scFvs, and the best-isolated phage from DAb Library (Clone No. $B_{1}$ ) was used for designing sandwich ELISA.

\section{Expression and purification of $\mathrm{G}_{2} \mathrm{scFv}$}

To improve the expression of recombinant anti-ETX $\mathrm{G}_{2}$ $\mathrm{scFv}$, the nucleotide sequence of the gene encoding antiETX $G_{2} \mathrm{scFv}$ was subcloned into the pET26b(+) vector using NotI and NcoI restriction enzymes. Following subcloning and transformation, the presence of the fulllength insert of a subcloned gene was analyzed by double digestion using the above restriction enzymes.

After expression, soluble $G_{2} \mathrm{scFv}$ was purified by nickel affinity chromatography and then analyzed by SDS-PAGE and Western blotting using HRP-conjugated monoclonal anti-polyhistidine antibody. The SDS-PAGE analysis confirmed the successful expression of the gene $\mathrm{G}_{2} \mathrm{scFv}$ in E. coli BL21 (DE3) and also the presence of soluble $G_{2} s c F v$ after extraction and purification steps.
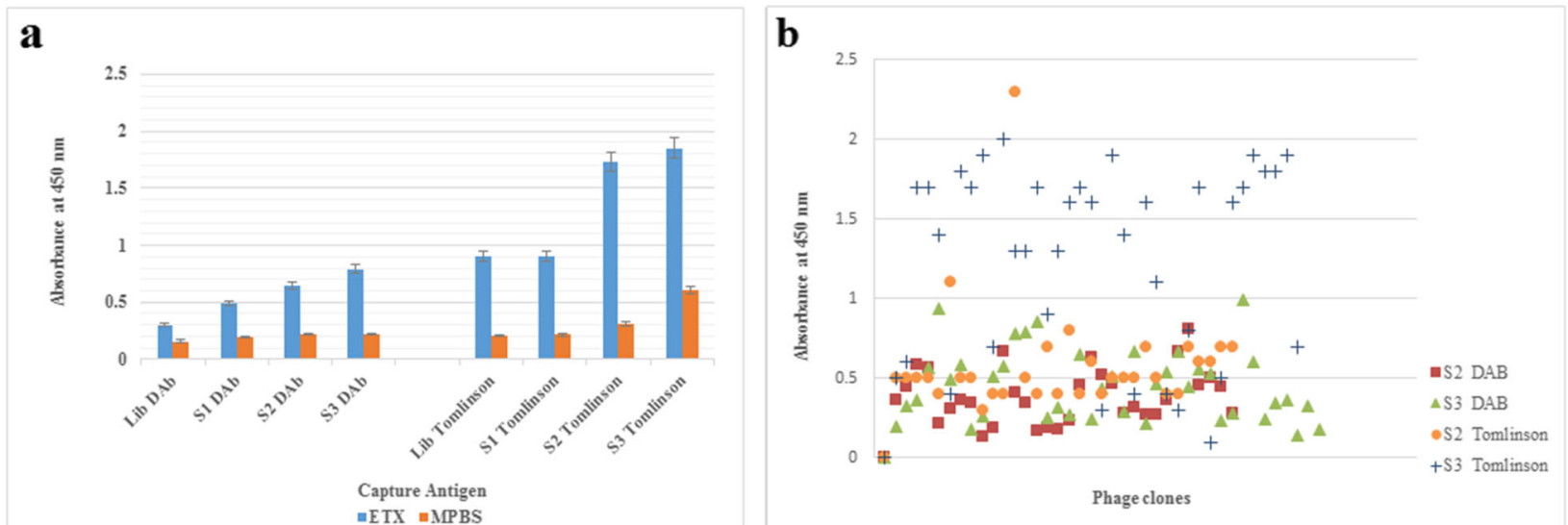

Fig. 1 a. Screening of clones by polyclonal phage ELISA. Epsilon toxoid was coated to plastic and then detected with an anti-c-Myc antibody. The coating was carried out in duplicate; the mean value is presented, the error bars indicat the standard deviation of the two values. 5\% MPBS buffer was coated as a negative control. $S_{1}, S_{2}, S_{3}=$ selection rounds 1, 2 and 3. b. Screening of clones by monoclonal phage ELISA of Tomlinson $I+J$ and DAb libraries. Individual phage clones from the second and third rounds of selection were tested by monoclonal phage ELISA against purified epsilon toxoid. Phages were applied as follows; $\mathrm{S}_{2}: 32$ clones picked at random after round 2 of selection; $\mathrm{S}_{3}: 36$ clones picked at random after round 3 of selection. OD at $450 \mathrm{~nm}$ was measured after 10 minutes. 
The Western blot result confirmed $\mathrm{G}_{2}$ scFv antibody recognition.

\section{Development of an ETX sandwich ELISA for quantitative detection of ETX}

An ETX sandwich ELISA test was designed to determine the concentration of ETX using two recombinant antibodies isolated from the DAb and Tomlinson I+ $\mathrm{J}$ libraries as shown in Fig. 2. The results of titration showed that the optimal concentration of the capture $\mathrm{B}_{1}$ phage $\mathrm{VH}$ antibody was $25 \mu \mathrm{g} / \mathrm{ml}(100 \mu \mathrm{l})$, and the detector $\mathrm{G}_{2} \mathrm{scFv}$ antibody was $50 \mu \mathrm{g} / \mathrm{ml}$ $(100 \mu \mathrm{l})$. Also, 1:5000 HRP-conjugated anti-his-tag antibody was used as the conjugated antibody. The standard curve of the double-recombinant antibody sandwich ELISA for epsilon toxoid with $R^{2}=0 / 997$ was calculated using GraphPad Prism 8 software and 4- parameter logistic curve $(4 \mathrm{pl})$ to fit the standard curve (Fig. 3). The limits of detection (LOD), limits of quantification (LOQ) were calculated by the standard formula as mentioned in the Methods section. LoD and LoQ were $5.37 \mathrm{ng} / \mathrm{ml}$ and $115.36 \mathrm{ng} / \mathrm{ml}$, respectively. The approximate detection range was about $120 \mathrm{ng} / \mathrm{ml}$ to $50,000 \mathrm{ng} / \mathrm{ml}$. The CV\% of standards and a vaccine sample concentration are presented in Table 1.

\section{Discussion}

Previous studies reported many problems with commercial enterotoxemia vaccines, such as the difference in antigen concentration and potency of the vaccine from batch to batch which cause inequality of antigen concentration distributed in each injection vial $[8,11,15,16]$ so that potency of the vaccine varies from batch to batch $[9,10,17]$. In order to detect and measure the C. perfringens epsilon toxoid in each batch, and evaluatethe immunogenicity of vaccines prepared, we developed an ETX sandwich ELISA test using specific recombinant antibodies against pure $C$. perfringens epsilon toxoid. We used recombinant antibodies because recombinant monoclonal antibody fragments have several advantages in comparison with conventional monoclonal antibodies and have been proposed as alternative tools for various diagnostic purposes $[18,19]$. These proteins can be easily and economically produced in various expression systems, for example, E. coli, plant, yeast, and cell culture and their biological activities can be readily improved by in vitro techniques $[19,20]$.

To isolate specific antibodies against the important epsilon toxoid, we used the two DAb and Tomlinson I + J phage display libraries. These libraries have billions of different antibody fragments built simultaneously with high expression, proper folding and low toxicity for $E$. coli cells. After three rounds of selection, and evaluation

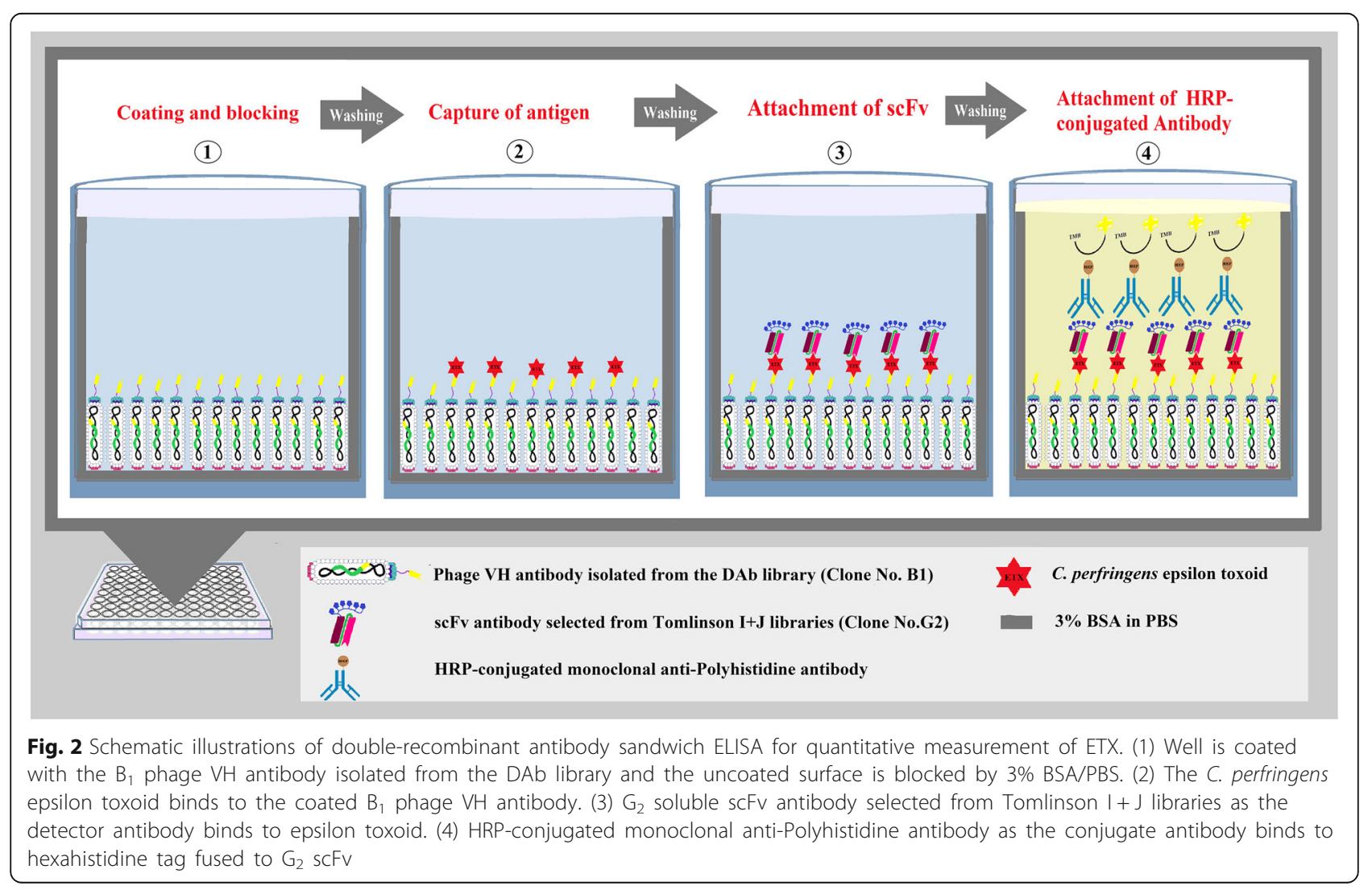




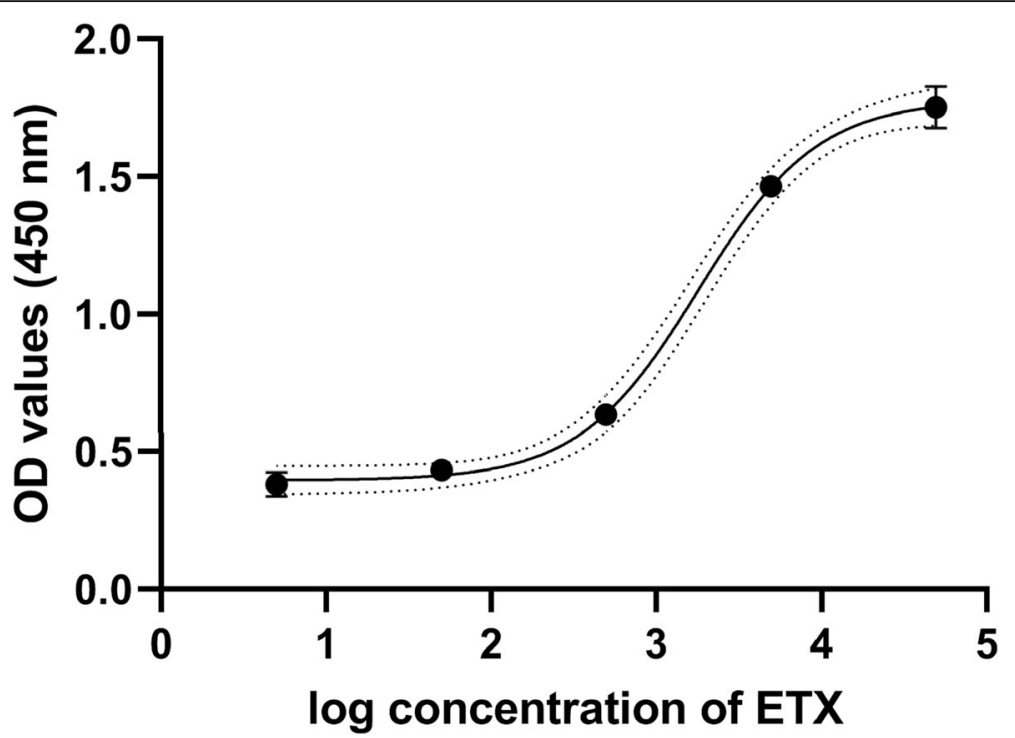

Fig. 3 The standard curve of the double-recombinant antibody sandwich ELISA for epsilon toxoid with $R^{2}=0 / 997$. Each point is the mean \pm standard deviation $(n=2)$

by polyclonal and monoclonal phage ELISA, several clones from rounds two and three showed high reactivity against ETX toxoid. Nine of the best clones were chosen for further experiments. Finally, clone $B_{1}$ from DAb library for producing anti-ETX phage antibody and clone $\mathrm{G}_{2}$ from Tomlinson I+ J libraries were used for making anti-ETX scFv to design the ETX sandwich ELISA.

As previously indicated, the double antibody sandwich ELISA has higher sensitivity and specificity than indirect ELISA, which can accurately quantify antigens with simple operation [21-24]. We designed a sandwich ELISA for the measurement of the C. perfringens epsilon toxoid. Both purified anti-ETX scFv and purified anti-ETX phage antibody were evaluated as a capture antibody for coating microtiter plates or as detector antibody, and their affinity and efficiency toward antigen were checked. Then, the coated plates were tested for dose-dependent reactions against a dilution series of ETX.

The results showed our phage antibody fragment can capture antigen much better than $\mathrm{scFv}$ antibody (data not shown). Then, the optimum concentration of both recombinant anti-ETX antibodies were applied for testing dose-dependent reactions against a dilution series of ETX and an inactivated enterotoxemia commercial vaccine (Razi Vaccine and Serum Research Institute (RVSR I)). Fortunately, the designed sandwich ELISA test was able to determine the concentration of ETX in the commercial vaccine.

In summary, we isolated two recombinant monoclonal antibodies $\left(B_{1}\right.$ and $\left.G_{2}\right)$ with a high affinity to ETX from

Table 1 A vaccine sample concentration ( $\mathrm{ng} / \mathrm{ml}$ ) obtained from calibration curve

\begin{tabular}{|c|c|c|c|c|c|c|c|c|}
\hline \multicolumn{5}{|c|}{ Optical density (450 nm) } & \multicolumn{4}{|c|}{ Vaccine sample conc $(\mathrm{ng} / \mathrm{ml})$} \\
\hline Std Conc (ng/ml) & Values & Mean & SD & CV\% & Values & Mean & SD & $\mathrm{CV} \%$ \\
\hline 5 & $\begin{array}{l}0.413 \\
0.352\end{array}$ & 0.3825 & 0.043134 & 11.31 & $\begin{array}{l}2039 \\
2350\end{array}$ & 2194 & 219 & 10 \\
\hline 50 & $\begin{array}{l}0.441 \\
0.426\end{array}$ & 0.4335 & 0.010607 & 2.44 & & & & \\
\hline 500 & $\begin{array}{l}0.638 \\
0.635\end{array}$ & 0.6365 & 0.002121 & 0.31 & & & & \\
\hline 5000 & $\begin{array}{l}1.459 \\
1.471\end{array}$ & 1.465 & 0.008485 & 0.54 & & & & \\
\hline 50,000 & $\begin{array}{l}1.806 \\
1.699\end{array}$ & 1.7525 & 0.07566 & 4.28 & & & & \\
\hline
\end{tabular}


two synthetic libraries by phage display technology. We established a sandwich ELISA using the $B_{1}$ phage antibody for capture and $G_{2} s c F v$ antibody fragment as a detector of ETX. This sandwich ELISA could be used for quick detection of ETX and monitoring vaccine quality of commercial enterotoxaemia vaccines.

\section{Conclusions}

The results of this study show that the designed ETX sandwich ELISA is a rapid, sensitive, and reliable method for quantitative detection of ETX and assessment of ETX in commercial vaccines against enterotoxemia.

\section{Methods}

The Tomlinson I + J human single fold synthetic naïve phage display single-chain antibody fragment $(\mathrm{scFv})$ libraries constructed in $\mathrm{pIT}_{2}$ (HIS MYC tag) vector with the size of $1.4 \times 10^{8}$ for each, and DAb human VH domain library constructed in $\mathrm{PR}_{2}$ (MYC VSV tag) with the size of $3 \times 10^{9}$, helper phage KM13, E. coli strains $\mathrm{TG}_{1}$ and $\mathrm{HB}_{2151}$ for selection of specific antibody clones and production of phage and soluble single-chain Fvs antibodies, respectively, were purchased from GeneService (Cambridge, UK). C. perfringens epsilon toxoid was purchased from National Institute for Biological Standards and Control (NIBSC), UK.

\section{Biopanning of phage display libraries}

The purity of the epsilon toxoid was initially confirmed by SDS-PAGE. The libraries and KM13 helper phage stocks were amplified to have enough quantities for use in several rounds of selection. Biopanning was performed using Tomlinson I + J and DAb libraries in parallel to ensure the researchers select the most epsilon toxoid binding clones. For selection, MaxiSorp ${ }^{\circ}$ immunotubes (Nunc, Denmark) were coated with $5 \mathrm{ml}$ pure C. perfringens epsilon toxoid $(100 \mu \mathrm{g} / \mathrm{ml})$ in carbonate buffer ( $\mathrm{pH}$ 9.4) and incubated overnight at $4{ }^{\circ} \mathrm{C}$, washed three times with PBS and blocked with 4\% MPBS (4\% Dry skimmed milk in PBS) buffer overnight at $4{ }^{\circ} \mathrm{C}$. The next day, $5 \times 10^{12}$ purified phages from each library in $5 \mathrm{ml}$ MPBS buffer were added to each immunotube and incubated for one hour with gentle agitation at room temperature. The unbound phages were removed by washing 10 times with PBS containing 0.1\% Tween 20 and twice with PBS buffer. To recover bound phages, $5 \mathrm{ml}$ trypsin solution $(1 \mathrm{mg} / 10 \mathrm{ml})$ was added to each immunotube and incubated for one hour at room temperature with gentle agitation. Then, eluted phages $(5 \mathrm{ml})$ were used to infect exponentially growing $E$. coli $\mathrm{TG}_{1}(30 \mathrm{ml})$, incubated at $37^{\circ} \mathrm{C}$ for one hour in a water bath and plated onto TYE agar plates $(100 \mu \mathrm{g} / \mathrm{ml}$ ampicillin, $4 \%$ glucose) and incubated at $30{ }^{\circ} \mathrm{C}$ overnight. The following day, cells were scraped from agar plates and diluted into $500 \mathrm{ml}$ of $2 \times \mathrm{TY}$ medium $(100 \mu \mathrm{g} / \mathrm{ml}$ ampicillin, 4\% glucose) and infected with KM13 phage. Then, grown phages were precipitated and purified by cold PEG/NaCl solution (20\% Polyethylene glycol 6000, $2.5 \mathrm{M} \mathrm{NaCl})$. The purified phages were used in the next round of selection and repeated binding, elution and infection steps for 2 times.

\section{Screening of clones by polyclonal phage ELISA}

The screening was done with the entire population of phages eluted (fused to the antibody fragments) after each round of selection. ELISA plates (Nunc, Denmark) were coated with epsilon toxoid $(100 \mu \mathrm{g} / \mathrm{ml})$ overnight at $4{ }^{\circ} \mathrm{C}$. The next day, plates were washed and blocked by $4 \%$ MPBS buffer per well. After washing, $10 \mu \mathrm{l}$ of PEG precipitated phages recovered from each round of selection were diluted in $100 \mu \mathrm{l}$ MPBS buffer and added to each well. One hour later, plates were washed and the binding of phages were detected using a monoclonal anti-c-Myc antibody (Biolegend) and anti-mouse HRP conjugate (Sigma Aldrich, USA) and detected with TMB substrate (Biobasic, Canada). Sulfuric acid solution $1 \mathrm{M}$ was used to stop the reaction and enzymatic activity of HRP-antibody conjugate and the absorbance was read at $450 \mathrm{~nm}$ and $620 \mathrm{~nm}$ with a microplate reader.

\section{Screening of clones by monoclonal phage ELISA}

For monoclonal phage ELISA, individual colonies were picked after the second and third rounds of selection and grown into 2 xTY medium containing $100 \mu \mathrm{g} / \mathrm{ml}$ ampicillin and $4 \%$ glucose in a 96 -well plate and incubated at $37{ }^{\circ} \mathrm{C}, 250 \mathrm{rpm}$ for 12 hours. Then, the overnight culture for each clone diluted 100-fold into $200 \mu \mathrm{l}$ 2xTY medium $(100 \mu \mathrm{g} / \mathrm{ml}$ ampicillin and $0.1 \%$ glucose $)$ and incubated at $37{ }^{\circ} \mathrm{C}, 250 \mathrm{rpm}$ until OD600 $=0.4$. The culture was infected with $4 \times 10^{8} \mathrm{KM} 13$ helper phages for $30 \mathrm{~min}$ at $37^{\circ} \mathrm{C}$, the bacteria pelleted by centrifugation and resuspended in $150 \mu \mathrm{l}$ of $2 \times \mathrm{YT}$ containing ampicillin $(100 \mu \mathrm{g} / \mathrm{ml})$ and kanamycin $(50 \mu \mathrm{g} / \mathrm{ml})$ before growth overnight at $25{ }^{\circ} \mathrm{C}, 250 \mathrm{rpm}$ for 16 hours. Then, the plate was centrifuged and $100 \mu \mathrm{l}$ of culture supernatant of each well was used for ELISA plates that precoated with epsilon toxoid $(100 \mu \mathrm{g} / \mathrm{ml})$ and blocked with $4 \%$ MPBS buffer. Phage binding was detected with a monoclonal anti-c-Myc antibody (Biolegend) and antimouse HRP conjugate (Sigma).

\section{Screening of clones by scFv ELISA}

Antibodies fused to the pIII coat protein of phage were converted to soluble scFv proteins by induction of bacteria with IPTG. scFv ELISAs were done similar to monoclonal phage ELISA. Soluble scFvs were produced by induction of culture of individual bacterial colonies at absorbance of about 0.9 at OD of $600 \mathrm{~nm}$ with $1 \mathrm{mM}$ of 
IPTG and growth for 16 hour at $25{ }^{\circ} \mathrm{C}, 250 \mathrm{rpm}$ in $2 \times$ YT. For ELISA, the culture supernatants that contained soluble scFvs were transferred to the antigen-coated wells of ELISA plates. Bound scFvs were detected using 1:5000 monoclonal anti-Polyhistidine HRP conjugate (Sigma Aldrich, USA).

\section{Expression and purification of scFvs}

The best clone of scFv ELISA from Tomlinson I+ J libraries (Clone No. $G_{2}$ ) was tested to confirm the presence of full-length insert by double digestion.

To improve the expression of anti-ETX scFv, the gene of selected clone $\left(\mathrm{G}_{2}\right)$ was subcloned between the NcoI and NotI restriction sites of the pET26b $(+)$ vector. The pET26b (+) vector contains the kanamycin resistance marker and carries an $\mathrm{N}$-terminal pelB signal sequence for potential periplasmic localization in addition to an optional C-terminal His Tag sequence. $\mathrm{CaCl}_{2}$-treated $E$. coli BL21 (DE3) was used as the host strain and transformation was performed using the heat shock method. $\mathrm{G}_{2} \mathrm{scFv}$ antibody was expressed using $0.01 \mathrm{mM}$ IPTG for 24 hour at $25{ }^{\circ} \mathrm{C}$. To extract the antibody, one gram of pelleted cell was resuspended in $5 \mathrm{ml}$ ice-cold protein extraction buffer (50 mM Tris- $\mathrm{HCl}, 1 \mathrm{mM}$ EDTA, $0.1 \%$ Triton $\mathrm{X}_{100}$ and $300 \mu \mathrm{g} / \mathrm{ml}$ lysozyme, $\mathrm{pH}$ 7.8) and was incubated for $30 \mathrm{~min}$ on ice. Then, the sample was sonicated at 24-25\% amplitude for $6 \mathrm{sec}$ ON and $6 \mathrm{sec}$ OFF cycle on ice and total sonication time was $10 \mathrm{~min}$. Following centrifugation at $10,000 \mathrm{~g}$ for 10 minutes at $4{ }^{\circ} \mathrm{C}$ supernatant containing total protein was mixed with $500 \mathrm{mM} \mathrm{NaCl}$ and $20 \mathrm{mM}$ imidazole to purify the scFv protein by Ni-NTA affinity chromatography. Samples were loaded at a speed of $1 \mathrm{ml} / \mathrm{min}$ onto the affinity column that had previously been equilibrated with cold binding buffer $(50 \mathrm{mM}$ Tris- $\mathrm{HCl}, 500 \mathrm{mM} \mathrm{NaCl}$ and $20 \mathrm{mM}$ imidazole, $\mathrm{pH}$ 7.4). Unrelated bacterial proteins were eluted with binding buffer containing $50 \mathrm{mM}$ imidazole before $\mathrm{scFv}$ recovery with binding buffer containing $400 \mathrm{mM}$ imidazole. The purified protein fractions containing anti-ETX scFv were analyzed by SDS-PAGE and western blotting.

\section{Development a sandwich ELISA for quantitation of ETX}

The sandwich ELISA was designed using $B_{1}$ (the best clone isolated from DAb library) phage antibody as a capture antibody and soluble $\mathrm{G}_{2} \mathrm{scFv}$ (the best clone isolated from Tomlinson I + J libraries) as a detection antibody. The optimal concentrations of capture $(100 \mu \mathrm{g} / \mathrm{ml}$ to $0.005 \mu \mathrm{g} / \mathrm{ml})$ and detection $(100 \mu \mathrm{g} / \mathrm{ml}$ to $0.005 \mu \mathrm{g} /$ $\mathrm{ml}$ ) antibody were determined by checkerboard titration. To obtain a standard curve of the sandwich ELISA, microtiter plates were coated with $100 \mu \mathrm{l}(25 \mu \mathrm{g} / \mathrm{ml})$ capture phage $\mathrm{VH}$ antibody $\left(\mathrm{B}_{1}\right)$ for overnight at $4{ }^{\circ} \mathrm{C}$. After washing and blocking with 3\% BSA/PBS (3\% BSA in
PBS), the $100 \mu \mathrm{l} 10$-fold serial dilutions of pure C. perfringens epsilon toxoid antigen from 5 to $50,000 \mathrm{ng} / \mathrm{ml}$ were added into the wells and incubated at $37^{\circ} \mathrm{C}$ for 1 hour. The wells were washed five times with PBST $(0.1 \%$ Tween-20 in PBS) buffer and once with PBS buffer and then $100 \mu \mathrm{l}(50 \mu \mathrm{g} / \mathrm{ml}) \mathrm{G}_{2} \mathrm{scFv}$ antibody was added into the wells and incubated at $37{ }^{\circ} \mathrm{C}$ for 1 hour. Subsequently, 1:5000 dilution of HRP-conjugated monoclonal anti-Polyhistidine antibody as the conjugate antibody was added into all wells after washing. Subsequent addition of TMB substrate, the OD value was measured at $450 \mathrm{~nm}$. The standard curve of the sandwich ELISA, were calculated using GraphPad Prism 8 software and 4parameter logistic curve (4pl) to fit the standard curve. The limits of detection (LOD), limits of quantification (LOQ) were calculated based on the standard deviation of the blank $(n=6)$ as follows [25]:

$$
\begin{aligned}
\text { LOD }= & \text { Mean }(\text { Blank })+3.3 \\
& \times \text { Stdev blank }(\text { one sided } 95 \% \times 2) \\
\text { LOQ }= & \text { Mean blank }+10 \\
& \times \text { Stdev blank }(\text { one sided } 95 \% \times 6)
\end{aligned}
$$

The designed ETX sandwich ELISA test was used to determine the concentration of ETX in an inactivated enterotoxemia commercial vaccine (RVSRI).

\section{Abbreviations \\ CDC: Centers for Disease Control and Prevention; ELISA: Enzyme-Linked Immunosorbent Assay; ETX: Epsilon toxin; DAb: Human domain antibody; PEG: Polyethylene glycol; RVSRI: Razi Vaccine and Serum Research Institute; scFv: Single-chain antibody fragment}

\section{Acknowledgements}

We would like to express our special thanks to Dr. Neda Eskandarzadeh (Assistant professor of biochemistry, Shahid Bahonar University of Kerman) and Dr. Maryam Ansari-Lari (Professor of epidemiology, Shiraz University) and Dr. Narges Eskandari Roozbahani (Research assistant, Clinical Research Development Center, Imam Reza Hospital, Kermanshah) for their support and guidance to validate the processes.

\section{Authors' contributions}

MA: Conceived and performed the experiments; analyzed and interpreted the data; wrote the manuscript. MG: Developed the study protocol; assisted with data interpretation, drafted and revised the manuscript, supervised the project. MT: Helped in planning the project; contributed to revision of the manuscript; supervised the project. All authors read, edited, and approved the final version of the manuscript.

\section{Funding}

This work was supported by Shiraz University and Ministry of Science, Research and Technology [grant number 9330154] and the Faculty of Veterinary Medicine, Shahid Bahonar University of Kerman. The funding body was solely involved in funding and had no role in the design of the study, in the collection, analysis, and interpretation of the data, or in the writing of the manuscript.

\section{Availability of data and materials}

All data generated or analyzed during this study are included in this published article and supplementary information files.

Ethics approval and consent to participate

Not applicable. 


\section{Consent for publication}

Not applicable.

\section{Competing interests}

The authors declare that they have no conflicts of interest associated with this study.

\section{Author details}

${ }^{1}$ Department of Pathobiology, Faculty of Veterinary Medicine, Shiraz University, Shiraz, Iran. ${ }^{2}$ Department of Pathobiology, Faculty of Veterinary Medicine, Shahid Bahonar University of Kerman, Kerman, Iran.

Received: 30 April 2020 Accepted: 15 September 2020

Published online: 29 September 2020

\section{References}

1. Popoff MR. Epsilon toxin: a fascinating pore-forming toxin. FEBS J. 2011;278: $1-20$.

2. Alves GG, Machado de Avila RA, Chavez-Olortegui CD, Lobato FCF. Clostridium perfringens epsilon toxin: The third most potent bacterial toxin known. Anaerobe. 2014;30:102-7. doi:https://doi.org/10.1016/j.anaerobe. 2014.08.016.

3. Nagahama M, Hara H, Fernandez-Miyakawa M, Itohayashi Y, Sakurai J. Oligomerization of Clostridium perfringens $\varepsilon$-toxin is dependent upon membrane fluidity in liposomes. Biochemistry. 2006;45:296-302. doi: https://doi.org/10.1021/bi051805s.

4. Minami J, Katayama S, Matsushita O, Matsushita C, Okabe A. Lambda-toxin of Clostridium perfringens activates the precursor of epsilon-toxin by releasing its $\mathrm{N}$-and C-terminal peptides. Microbiol Immunol. 1997;41:527-35. doi:https://doi.org/10.1111/j.13480421.1997.tb01888.x.

5. Miyata S, Matsushita O, Minami J, Katayama S, Shimamoto S, Okabe A. Cleavage of a C-terminal peptide is essential for heptamerization of Clostridium perfringens $\varepsilon$-toxin in the synaptosomal membrane. J Biol Chem. 2001;276:13778-83. doi:https://doi.org/10.1074/jbc.M011527200.

6. Dorca-Arévalo J, Soler-Jover A, Gibert M, Popoff MR, Martín-Satué M, Blasi J. Binding of $\varepsilon$-toxin from Clostridium perfringens in the nervous system. Vet Microbiol. 2008;131:14-25. doi:https://doi.org/10.1016/j.vetmic.2008.02.015.

7. Nestorovich EM, Karginov VA, Bezrukov SM. Polymer partitioning and ion selectivity suggest asymmetrical shape for the membrane pore formed by epsilon toxin. Biophys J. 2010;99:7829. doi.https://doi.org/10.1016/j.bpj.2010. 05.014.

8. Nijland R, Lindner C, van Hartskamp M, Hamoen LW, Kuipers OP. Heterologous production and secretion of Clostridium perfringens $\beta$-toxoid in closely related Gram-positive hosts. JBiotechnol. 2007;127:361-72. doi: https://doi.org/10.1016/j.jbiotec.2006.07.014.

9. Thaysen-Andersen M, Jorgensen SB, Wilhelmsen ES, Petersen JW, Hojrup P. Investigation of the detoxification mechanism of formaldehyde-treated tetanus toxin. Vaccine. 2007;25:2213-27. doi:https://doi.org/10.1016/j.vaccine. 2006.12.033.

10. Veschi JLA, Dutra IS, Alves MAB, Perri SHV, Zafalon LF, Fernandez-Miyakawa ME. Sorological evaluation of polyvalent commercial vaccines against enterotoxemia in goats. Ars Vet. 2012;28:222-6.

11. Salvarani FM, Conceicao FR, Cunha CEP, Moreira GMSG, Pires PS, Silva ROS, et al. Vaccination with recombinant Clostridium perfringens toxoids $\alpha$ and $\beta$ promotes elevated antepartum and passive humoral immunity in swine. Vaccine. 2013;31:4152-5. doi:https://doi.org/10.1016/j.vaccine.2013.06.094.

12. Morgeaux S, Poirier B, Ragan Cl, Wilkinson D, Arabin U, Guinet-Morlot F, et al. Replacement of in vivo human rabies vaccine potency testing by in vitro glycoprotein quantification using ELISA - Results of an international collaborative study. Vaccine. 2017;35:966-71. doi:https://doi.org/10.1016/j. vaccine.2016.12.039.

13. Wang Z, Sun Y, Wu X, Carroll DS, Lv W, You L, et al. Development of a relative potency test using ELISA for human rabies vaccines. Biologicals. 2018;55:59-62. doi:https://doi.org/10.1016/j.biologicals.2018.06.003.

14. Niu Y, Zhang P, Wang L, Li N, Lin Q, Liu L, et al. Development of doubleantibody sandwich ELISA for rapidly quantitative detection of antigen concentration in inactivated SCRV vaccine. Aquaculture. 2019. doi: https://doi.org/10.1016/j.aquaculture.2019.734671. September:734671.

15. Gonçalves LA, Lobato ZIP, Silva ROS, Salvarani FM, Pires PS, Assis RA, et al. Selection of a Clostridium perfringens type $D$ epsilon toxin producer via dot- blot test. Arch Microbiol. 2009;191:847-51. doi:https://doi.org/10.1007/ s00203-009-0510-y.

16. Titball RW. Clostridium perfringens vaccines. Vaccine. 2009;27 SUPPL. 4:D44-7.

17. Lobato FCF, Lima CGRD, Assis RA, Pires PS, Silva ROS, Salvarani FM, et al. Potency against enterotoxemia of a recombinant Clostridium perfringens type D epsilon toxoid in ruminants. Vaccine. 2010;28:6125-7. doi:https://doi.org/10.1016/j.vaccine.2010.07.046.

18. Oelschlaeger P, Srikant-lyer S, Lange S, Schmitt J, Schmid RD. Fluorophorlinked immunosorbent assay: a time-and cost-saving method for the characterization of antibody fragments using a fusion protein of a singlechain antibody fragment and enhanced green fluorescent protein. Anal Biochem. 2002;309:27-34. doi:https://doi.org/10.1016/s0003-2697(02)002907.

19. Weisser NE, Hall JC. Applications of single-chain variable fragment antibodies in therapeutics and diagnostics. Biotechnol Adv. 2009;27:502-20. doi:https://doi.org/10.1016/j.biotechadv.2009.04.004.

20. Golchin M, Khalili-Yazdi A, Karamouzian M, Abareghi A. Latex agglutination test based on single-chain Fv recombinant antibody fragment. Scand I Immunol. 2012;75:38-45. doi:https://doi.org/10.1111/j.1365-3083.2011.02621.x.

21. Hutchings GH, Ferris NP. Indirect sandwich ELISA for antigen detection of african swine fever virus: Comparison of polyclonal and monoclonal antibodies. J Virol Methods. 2006;131:213-7. doi:https://doi.org/10.1016/j. jviromet.2005.08.009.

22. Luo Y, Terkawi MA, Jia H, Aboge GO, Goo Y-K, Cao S, et al. A double antibody sandwich enzyme-linked immunosorbent assay for detection of secreted antigen 1 of Babesia microti using hamster model. Exp Parasitol. 2012;130:178-82. doi:https://doi.org/10.1016/j.exppara.2011.10.012.

23. Li J, Huang R, Xia K, Liu L. Double antibodies sandwich enzyme-linked immunosorbent assay for the detection of Alicyclobacillus acidoterrestris in apple juice concentrate. Food Control. 2014;40:172-6. doi:https://doi.org/10. 1016/j.foodcont.2013.11.037.

24. Ten Haaf A, Kohl J, Pscherer S, Hamann H-P, Eskens HU, Bastian M, et al. Development of a monoclonal sandwich ELISA for direct detection of bluetongue virus 8 in infected animals. J Virol Methods. 2017;243:172-6. doi:https://doi.org/10.1016/j.jviromet.2017.02.003.

25. Little TA. Method validation essentials, limit of blank, limit of detection, and limit of quantitation. BioPharm Int. 2015;28:48-51.

\section{Publisher's Note}

Springer Nature remains neutral with regard to jurisdictional claims in published maps and institutional affiliations.
Ready to submit your research? Choose BMC and benefit from:

- fast, convenient online submission

- thorough peer review by experienced researchers in your field

- rapid publication on acceptance

- support for research data, including large and complex data types

- gold Open Access which fosters wider collaboration and increased citations

- maximum visibility for your research: over $100 \mathrm{M}$ website views per year

At BMC, research is always in progress.

Learn more biomedcentral.com/submissions 